\title{
Night versus day abundance estimates of zooplankton at two coastal stations in British Columbia, Canada
}

\author{
W. Shaw ${ }^{1}$, C. L. K. Robinson ${ }^{2, *}$ \\ ${ }^{1}$ Fisheries and Oceans Canada, 3225 Stephenson Point Road, Nanaimo, British Columbia V9T 1K3, Canada \\ ${ }^{2}$ Northwest Ecosystems Institute, Box 513, Lantzville, British Columbia V0R 2H0, Canada
}

\begin{abstract}
Zooplankton abundance at 2 coastal stations in southern British Columbia, Canada, was estimated during the day and the night using oblique bongo net hauls. There were no statistically significant differences between night and day abundances when calanoid copepods or euphausiids were grouped by species or life history stage. However, statistically significant differences between night and day abundances were found when species and life history stages were considered separately. The euphausiids had the greatest differences between night and day catches. The maximum night to day (N:D) catch ratios were estimated to be 10.6 for Euphausia pacifica and 4.9 for Thysanoessa spinifera. $\mathrm{N}: \mathrm{D}$ ratios for E. pacifica showed large interannual and station variability, and varied by an order of magnitude. It is likely that several factors influence these N:D catch ratios, including tidal height, moonlight, and the temporal and spatial patchiness of the euphausiids. The majority of calanoid copepod genera examined had near equal N:D ratios. The highest copepod N:D catch ratios were found for large female copepods (e.g. Metridia pacifica or Eucalanus bungii), and they ranged from 2 to 8 . A few smaller calanoid copepod species had abundance estimates that were statistically higher during the day than the night (e.g. N:D $=0.3$, Oithona spp.). Overall, we conclude that N:D catch ratios of coastal zooplankton can vary widely within a species over space and time, and that the catch ratios appear to be related to body size: larger animals have higher catches at night. It is recommended that coastal studies using bongo nets to discretely sample copepods or euphausiids should include a $24 \mathrm{~h}$ component in the sampling program to quantify differences between night and day abundance estimates.
\end{abstract}

KEY WORDS: British Columbia 24 h sampling - Euphausiids Euphausia pacifica Night:day catch ratio

\section{INTRODUCTION}

Several recent studies have focused on understanding the impacts of a changing ocean climate on the production dynamics of important coastal marine fish populations (see articles in Beamish 1995) One aspect of this understanding is to identify and quantify linkages between the physical/chemical ocean environment and zooplankton communities. These linkages are critical because all developmental stages of most coastal marine fishes include some component of zooplankton in their diet. For example, juvenile herring and salmon feed on small zooplankters such as the

·Addressee for correspondence.E-mail: clkrnei@island.net calanoid copepods, while larger fishes such as Pacific hake and adult salmon feed on larger stages and species of zooplankton such as the euphausiids (Ware \& McFarlane 1995).

For more than $20 \mathrm{yr}$, the Canadian Department of Fisheries and Oceans (DFO) has conducted sampling surveys of zooplankton communities at several locations along the west coast of Vancouver Island, British Columbia, to provide data for investigations into linkages between ocean and fish productivity (e.g. Fulton et al. 1982, Simard \& Mackas 1989, Shaw 1994, Mackas 1995, Ware \& McFarlane 1995, Shaw unpubl. data). The DFO zooplankton sampling program has relied upon ship-of-opportunity research cruises, and grid-sampling programs such as the La Perouse Project 
(Ware \& Thomson 1991). For the most part, zooplankton sampling cruises have used relatively consistent sampling methodology and gear type (e.g. oblique bongo tows). However, one potentially important and overlooked source of variability in estimating zooplankton abundance and biomass during some of the DFO cruises may be the time of day that sampling occurred.

There are potentially large differences in zooplankton abundance or biomass estimates when sampling occurs during the day versus the night, particularly for macrozooplankton such as the euphausiids. For example, decreased daytime catches of euphausiids might be expected because of deeper daytime depths, due to diel vertical migrations, and differential avoidance of the sampler. Wiebe et al. (1982) summarized that the primary avoidance stimulus involves day-night variations in ambient light, and that vision is the primary means of net avoidance by euphausiids. Because some adult calanoid copepods reach a large enough size to vertically migrate in response to changing light conditions (Mauchline 1998), it follows that their catches may also differ between right and day samples.

The main objective of this study was to test the null hypothesis that there is no significant difference in zooplankton abundance estimates when sampling is conducted during the day versus night. We tested this hypothesis because of the importance in obtaining ground-truthed estimates of zooplankton abundance and biomass for use in process and modelling studies of coastal fish production dynamics (e.g. Robinson \& Ware 1994).

\section{MATERIALS AND METHODS}

Zooplankton sampling was conducted using a $60 \mathrm{~cm}$ diameter bongo net (with two $253 \mu \mathrm{m}$ black nitex mesh nets) during the spring of 1993,1994, and 1995 at 2 stations located in southern British Columbia (Table 1 , Fig. 1). The first station (SOFG) was located at $49^{\circ} 22^{\prime} \mathrm{N}, 124^{\circ} 05^{\prime} \mathrm{W}$ in the southern Strait of Georgia near Winchelsea Island. The water properties at SOFG are strongly influenced by seasonal discharge patterns of the Fraser River. The second station (WCVI) was located on the continental shelf off Barkley Sound, at $48^{\circ} 23.45^{\prime} \mathrm{N}, 125^{\circ} 20.80^{\prime} \mathrm{W}$. Water properties at WCVI are influenced by the Vancouver Island Coastal Current and the Juan de Fuca Eddy (Thomson et al. 1989).

At each station, bongo tows were conducted every 2 h over a 24 h period in 1994 and 1995; in addition bongo tows were conducted every $1 \mathrm{~h}$ at WCVI and every $2 \mathrm{~h}$ at SOFG in 1993. Oblique bongo tows were taken from within $5 \mathrm{~m}$ of the bottom to surface at both WCVI and SOFG. The bongo net was lowered at about $1 \mathrm{~m} \mathrm{~s}^{-1}$ and raised at $0.3 \mathrm{~m} \mathrm{~s}^{-1}$ obliquely to and from the maximum depth. During a tow, the ship's speed was kept at 3 to $6 \mathrm{~km} \mathrm{~h}^{-1}$ to maintain a wire angle between 30 and $50^{\circ}$. The wire angle and the amount of wire out were used to determine the depth at which the bongo net fished. The volume of water filtered during each tow was calculated from a calibrated, stainless steel TSK flowmeter mounted on the inside of the bongo net. After each tow, the outside of the bongo net was washed from the mouth toward the cod-end with a saltwater deck hose. The contents of each cod-end were then transferred to separate 1 litre glass jars, and fixed with buffered $7 \%$ formalin. See Shaw (1994) for more details about the standard sampling methods used.

Zooplankton samples were sorted at the Polish Sea Fisheries Institute Plankton Sorting and Identification Center in Szczecin, Poland, and detailed sorting methods are discussed in Siefert \& Incze (1991). Generally, samples of zooplankton from each tow were analyzed for species, stage (e.g. copepodite 4 , adult), size group (e.g. $<2 \mathrm{~mm},>20 \mathrm{~mm}$ ), and sex (male and female). For all samples, large organisms such as jellyfish were first removed and noted. The sample was split with a Folsom plankton splitter to obtain a subsample of about 100 to 200 organisms $>5 \mathrm{~mm}$ (maximum dimension). This first split was not made beyond $1 / 64$ of the original sample. Subsample sizes for organisms $<5 \mathrm{~mm}$ varied and were often small $(1 / 1024)$, with the first split

Table 1. Station characteristics and sampling dates for 2 stations sampled for zooplankton using a bongo net. All times in Pacific Daylight Savings Time. Start: time sampling started; SS: sunset; SR: sunrise; D: no. of day tows; N: no. of night tows; WCVI: west coast Vancouver Island station; SOFG: Strait of Georgia station

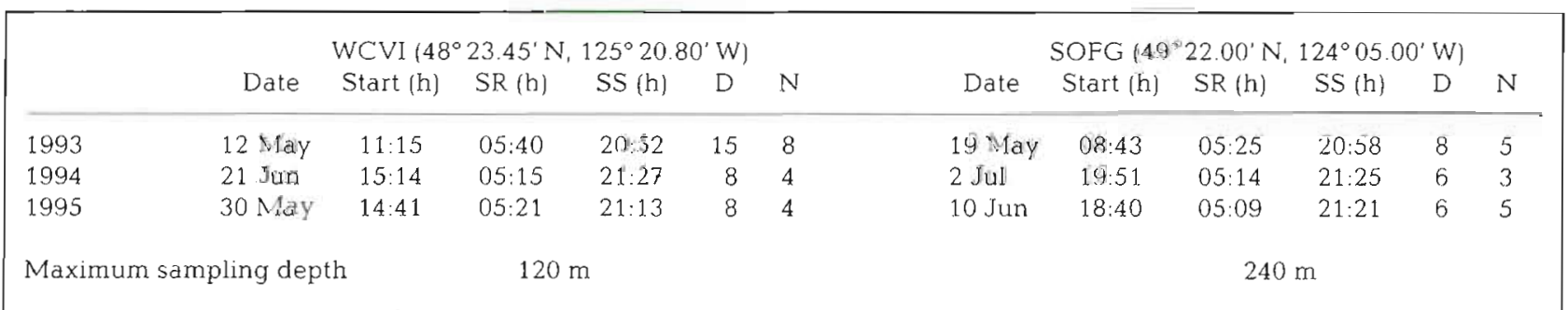




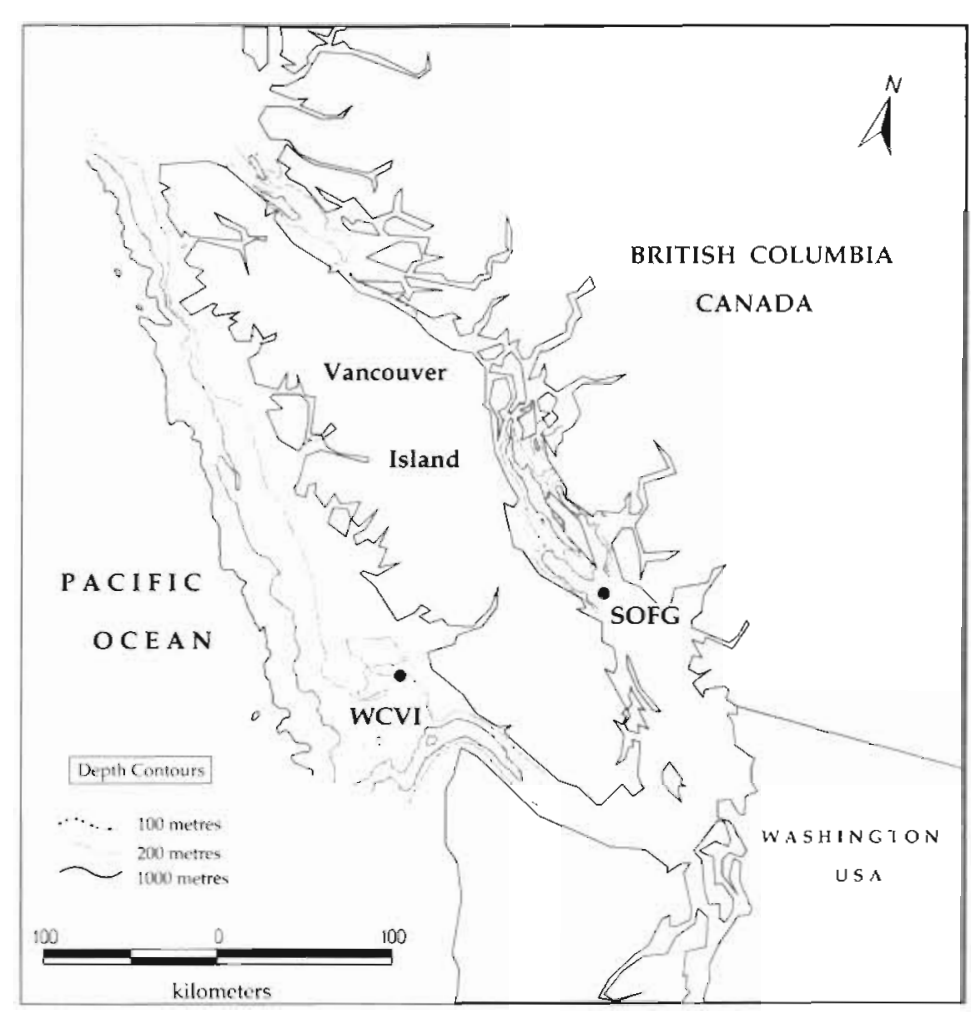

Fig. 1 Location of 2 sampling stations in southern British Columbia where day and night bongo net sampling was conducted in the spring of 1993, 1994 and 1995. SOFG: Strait of Georgia; WCVI: west coast Vancouver Island

containing 300 to 500 organisms. If the first subsample did not contain at least 30 specimens of a taxa or developmental stage, then a second subsample was sorted. The zooplankton data discussed in this study are archived by W. Shaw at the South Coast Division, Fisheries and Oceans Canada, Nanaimo, British Columbia, Canada.

\section{RESULTS}

To test the hypothesis that there were no significant differences between zooplankton abundances when sampled during the day versus night, we have analyzed the data by considering (1) 2 general groups of zooplankton: calanoid copepads and euphausiids, (2) 20 taxa of zooplankton, (3) life history stages and sexes of each zooplankton group in (1), and (4) life history stages and sexes of 4 calanoid copepod species. In each section, we discuss results for each sampling station and year separately, and in combination.

Before the analyses were conducted, each tow was designated as night (N) or day (D). If a tow occurred before sunrise or after sunset it was deemed a night tow (N), while tows occurring after sunrise and before sunset were designated as day tows (D). Sunrise and sunset were determined for local Pacific Daylight Savings Time (PDST) from the Nautical Atlas (Table 1).

$\mathrm{N}: \mathrm{D}$ catch ratios of zooplankton abundance (no. $\mathrm{m}^{-2}$ ) were calculated using arithmetic averages of night or day tows at a given station on a given date. Abundance frequency histograms were initially used to determine if the distribution of catch per taxa at each station, and for each day-night designation, was normal. If the night or day catches of a taxa were skewed, the abundances were log transformed. Tests of significance were performed on transformed data but untransformed averages were used to calculate the reported N:D catch ratios (Sokal \& Rohlf 1981). In all analyses, significant differences between abundances caught during night or day were tested for using a 2-sample $t$-test. We did not apply a multiple comparisons correction to alpha (e.g. Bonferroni; Rice 1989) because the question concerning significant $\mathrm{N}$ :D catch ratios was asked independently of each taxa. We had a priori expectations that the zooplankton taxa would have different $N: D$ ratios because they have different maximum sizes and responses to light, important factors contributing to the catchability of zooplankton (Mauchline 1998). We tested for significant differences only when $\mathrm{N}$ :D ratios were $>2$ or $<0.5$. At these ratios, there would be twice or half as many zooplankton caught at night versus day, respectively, and we consider estimates of this magnitude to be biologically significant.

Two major factors were considered before conducting the analyses: (1) relative sampling efficiency of the bongo net and (2) availability of zooplankton to the bongo net. Sampling efficiency of the bongo net was assessed by comparing tow duration with flowmeter readings (Fig. 2). There is evidence that 1 tow at WCVI-93 (at WCVI in 1993) and 2 tows at SOFG-93 had decreased flowmeter readings with tows lasting more than $30 \mathrm{~min}$ (SOFG) and $17 \mathrm{~min}$ (WCVI). Note that bongo tows made in 1994 and 1995 lasted <14 min at WCVI, and $<30 \mathrm{~min}$ at SOFG, and clogging is not considered a factor Fig. 2 suggests that the bongo net may have become clogged and did not sample efficiently during longer tows. However, we calculated $N$ :D catch ratios for 33 zooplankton taxa with and without the suspect tows, and found that 19 species had non-significantly higher $\mathrm{N}$ :D catch ratios and the remainder had non-significantly lower ratios. 

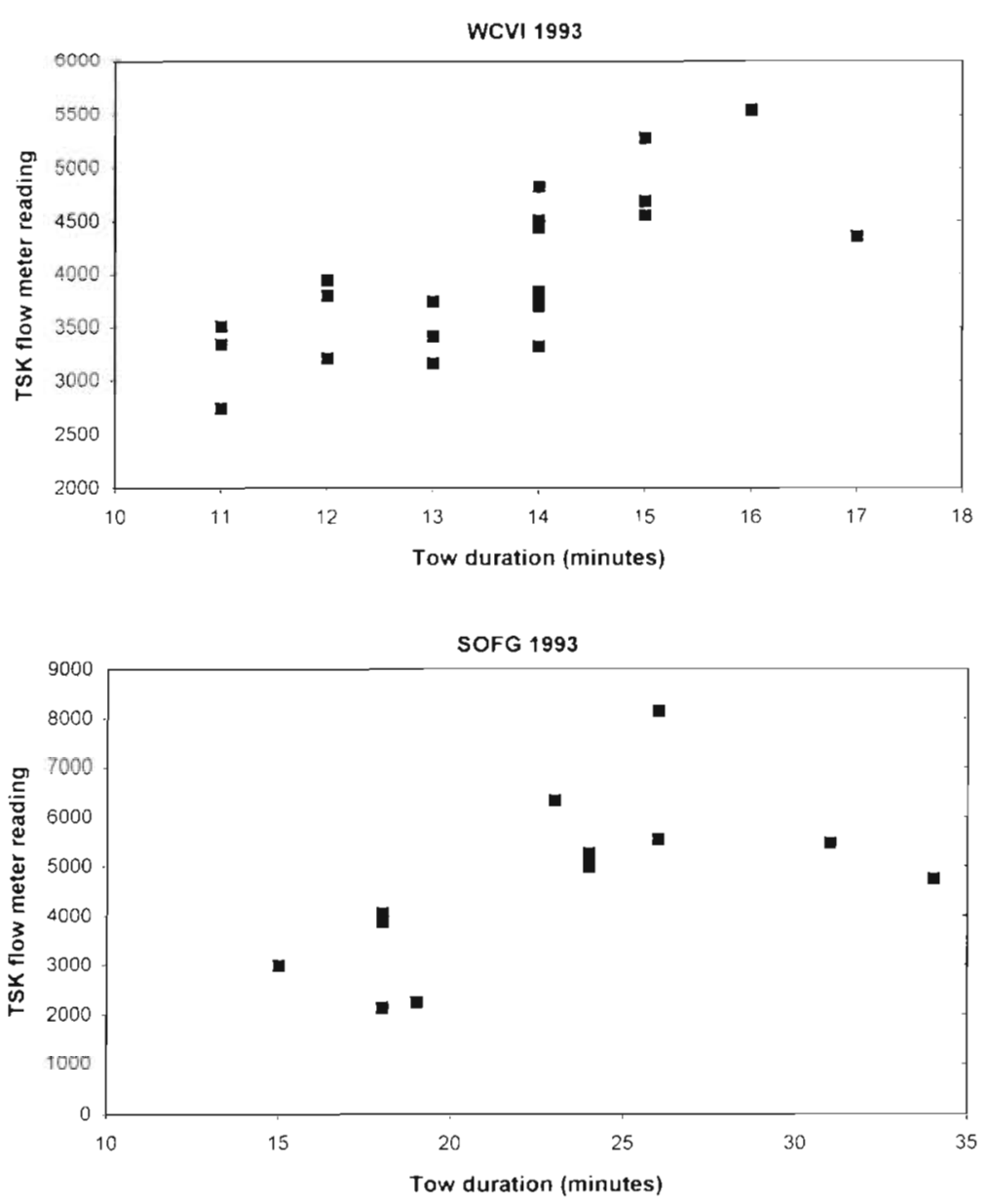

Fig. 2. Comparison of flowmeter readings with duration of bongo tows for SOFG and WCVI in 1993

were conducted between bongo tows at WCVI-94, and 3 at WCVI-95. The Tucker trawls at WCVI were towed for 11 to $20 \mathrm{~min}$ to a depth of $100 \mathrm{~m}$ and deployed/retrieved at about $1 \mathrm{~m} \mathrm{~s}^{-1}$ One Tucker tow was also conducted between 2 bongo tows at SOFG-94. The trawl at SOFG was towed for $<30 \mathrm{~min}$ to a depth of $200 \mathrm{~m}$ and deployed/retrieved at about $1 \mathrm{~m} \mathrm{~s}^{-1}$. Combined, 4 of the Tucker tows were conducted during the day and 4 at night.

During the night, the Tucker trawl caught 65 to $85 \%$ of the same species that the bongo nets caught, while during the day the Tucker trawl caught 89 to $124 \%$ of the species caught by the bongo nets. It seems that qualitatively both nets were sampling a similar zooplankton community. We also evaluated for quantitative differences between nets by comparing catches of large-bodied zooplankton, i.e. the euphausiids, because they have the greatest potential for net avoidance. The results indicate that 6 of 8 Tucker trawls gave higher average estimates of euphausiid abundance than did bongo tows conducted immediately before or after the trawl (Fig. 3). However, none of the differences in average abundance between Tucker trawl tows and bongo net hauls were found to be statistically significant.

\section{Groups of zooplankton}

Another test of the possible clogging of the bongo net is to compare flowmeter readings made between an internally and an externally mounted flowmeter. At WCVI, readings of the inside flowmeter were found to be $9 \%$ lower, on average, than the outside meter, while at $S O F G$ inside readings were $2 \%$ higher on average than the outside meter. Overall, the results suggest that sampling efficiencies of the bongo net tows were not significantly affected by clogging, and we retained data from all tows to increase the degrees of freedom in the statistical analyses.

The second factor we considered before conducting analyses was whether zooplankton were available to the bongo net. Strategies used to test the availability of zooplankton to samplers include reducing avoidance by increasing towing speed or increasing net mouth size (Wiebe et al. 1982). In this study, we chose the latter approach and compared bongo net catches of zooplankton with catches made from a $1 \mathrm{~m}$ by $2 \mathrm{~m}$ Tucker trawl. with a $253 \mu \mathrm{m}$ black mesh. Four Tucker tows
The subsamples of zooplankton were sorted into 2 general groups: calanoid copepods and euphausiids. Examination of the change in abundance at each station and year indicates that both groups responded in. similar ways to sampling conducted over the day, and that there were at least 3 possible patterns in the N:D catch ratios. One pattern identified indicates that zooplankton abundance estimates remained within a relatively small range over time, except for a very sudden 4- to 10-fold increase in abundance with 1 tow (Fig 4). $\mathrm{N}$ :D catch ratios for this pattern were generally below 1. This pattern may result from sampling a patch of zooplankton. A second pattern identified indicates that zooplankton abundance estimates fluctuate by up to 2 times even when sampling occurs every hour (Fig. 5). $\mathrm{N}$ :D catch ratios for this pattern typically approximated 1 The third pattern identified indicates that the highest $N$ :D catch ratios were associated with high night and low day catches of zooplankton, particularly for 


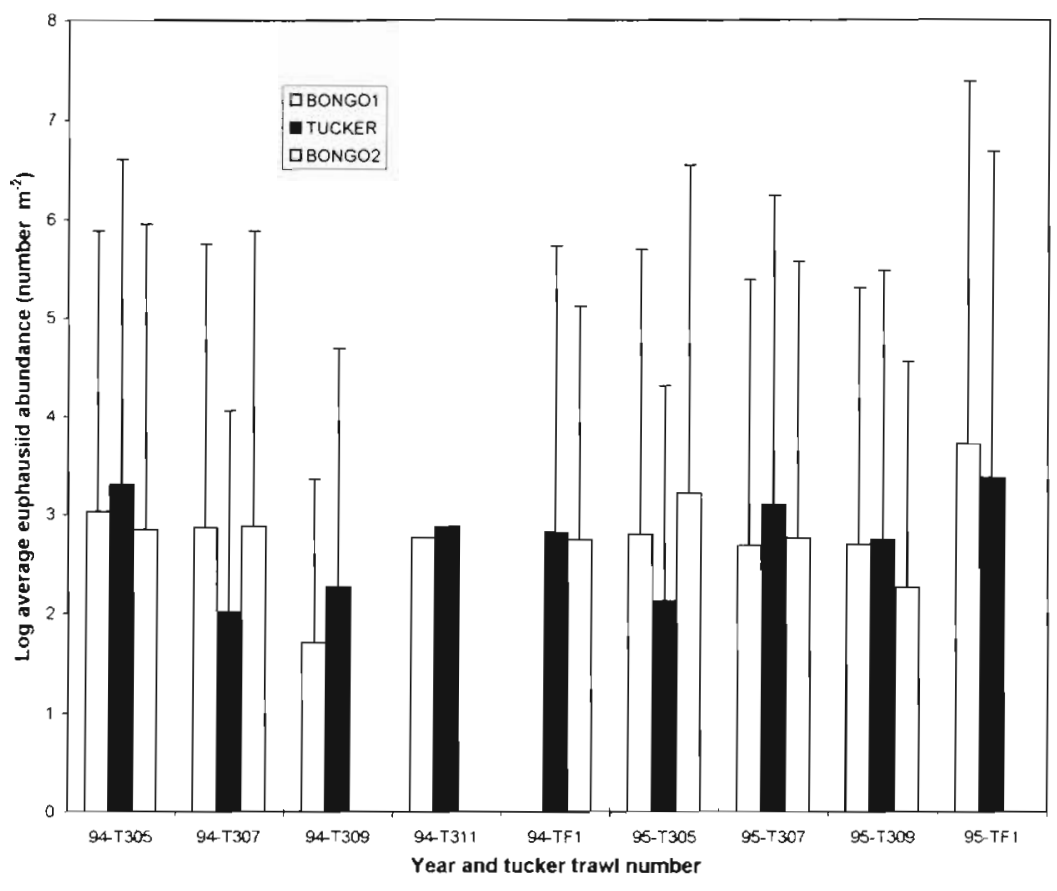

Fig. 3. Comparison of euphausid abundance estimates using a Tucker trawl and bongo hauls. Bongo hauls were performed immediately before and after the Tucker trawl. None of the differences are statistically significant $(p>0.05)$. Note: abundances represent averages and SD of all euphausiid species and stages caught

the larger animals such as the euphausiids. This pattern typically shows a relatively rapid decline in abundance as dawn approaches, and a rapid increase in abundance after dusk (Fig. 6). N:D catch ratios were typically $>2$.
Three copepods, Metridia pacifica, Calanus pacificus, and Clausocalanus spp., showed 1 occurrence each in which night catches were significantly higher than day catches $(\mathrm{N}: \mathrm{D}$ ratio = $4.5,2.6$ and 3.1 , respectively), while 3 other copepods (Oithona spp., Neocalanus spp., Pseudocalanus spp.) showed 1 occurrence each in which $N$ :D catch ratios were significantly less than 0.5 (Table 2), indicating that day catches were more than twice those of night catches.

\section{Zooplankton life history stages and sex}

We examined for differences in night and day catches of zooplankton segregated by life history stage and by sex for the 2 general groups of zooplankton, calanoid copepods and euphausiids, discussed above.

Six life history stages were identified for all calanoid copepods combined: copepodite 1 (C1), copepodite 2 (C2), copepodite 3 (C3), copepodite 4 (C4), copepodite 5 (C5), and adults. When the calanoid copepods were broken down by stage, 4 of 6 sampling periods show an increasing trend in N:D catch ratios with increasing stage size (Table 3). Note that for samples collected in 1995, there was a trend for higher N:D ratios with the smallest stage (copepodite 1 ).

\section{Zooplankton species}

Abundance estimates of 20 zooplankton taxa were examined for significant differences between day and night catches. Of the $102 \mathrm{~N}: \mathrm{D}$ ratios calculated, about $17 \%(\mathrm{n}=17)$ had significantly different day-night catch ratios: 9 had significantly higher night than day catches, while 8 had significantly higher day catches (Table 2). Of the significantly higher N:D catch ratios, the majority belonged to the euphausiids. Euphausia pacifica abundance in 4 of the 9 night catches was significantly higher than in day catches. The $\mathrm{N}: \mathrm{D}$ catch ratios of $E$. pacifica varied from 0.50 to 10.6 , with an overall average $\mathrm{N}: \mathrm{D}$ catch ratio of 4.3. A second euphausiid, Thysanoessa spinifera, had N:D catch ratios ranging from 1.6 to 4.9 , with an average $N: D$ catch ratio of 4.5 (Table 2 ).

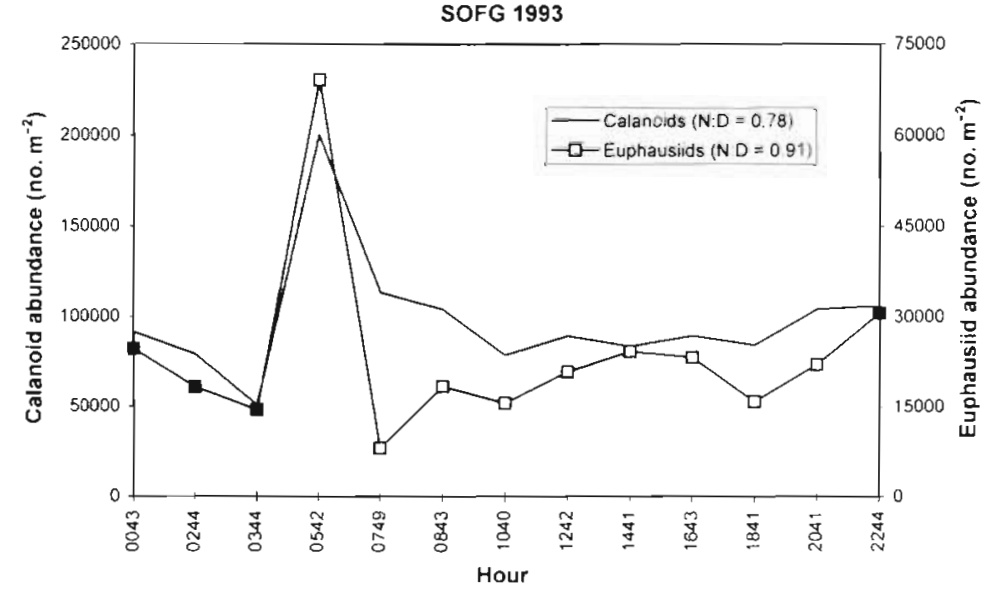

Fig. 4. Changes in calanoid copepod and euphausiid abundances over time, as determined from day (a) and night ( bongo tows at SOFG in 1993. Shown in parentheses are the estimated night:day (N:D) catch ratios 
Limited data were available describing changes in $\mathrm{N}: \mathrm{D}$ catch ratios for different life history stages of individual calanoid species. Of the 4 species (Calanus spp., Pseudocalanus spp., Eucalanus bungii, and Metridia pacifica) and 3 stages (C4, C5, adult) examined, only 4 of the 72 samples had significantly higher N:D catch ratios (Table 4 ).

An examination of the changes in abundance of males and females for the 4 copepod species indicates that females tend to have higher $\mathrm{N}: \mathrm{D}$ catch ratios (Table 4). There were several clear examples of higher night catches than day catches for females. For example, adult Metridia pacifica and adult Eucalanus bungii females showed N:D catches of 3.7 and 2.3, respectively (Fig. 7). Overall, female zooplankters had an average N:D ratio of 1.7 versus 1.2 for males. This result is consistent with the generally larger body size (length) of females.

Six life history stages were identified for the euphausijds: nauplius, furcilia, calyptopis 1, calyptopis 2 , calyptopis 3 , and adults. Analysis indicates that there were no statistically significant differences between night and day abundance estimates for stages smaller than adult (Table 5). However, in 5 of 6 instances adult euphausiids had statistically significantly higher abundance estimates when bongo sampling was conducted at night versus day. When data from all stations were combined the N:D catch ratio for adult euphausiids was 3.6. There were too few data to

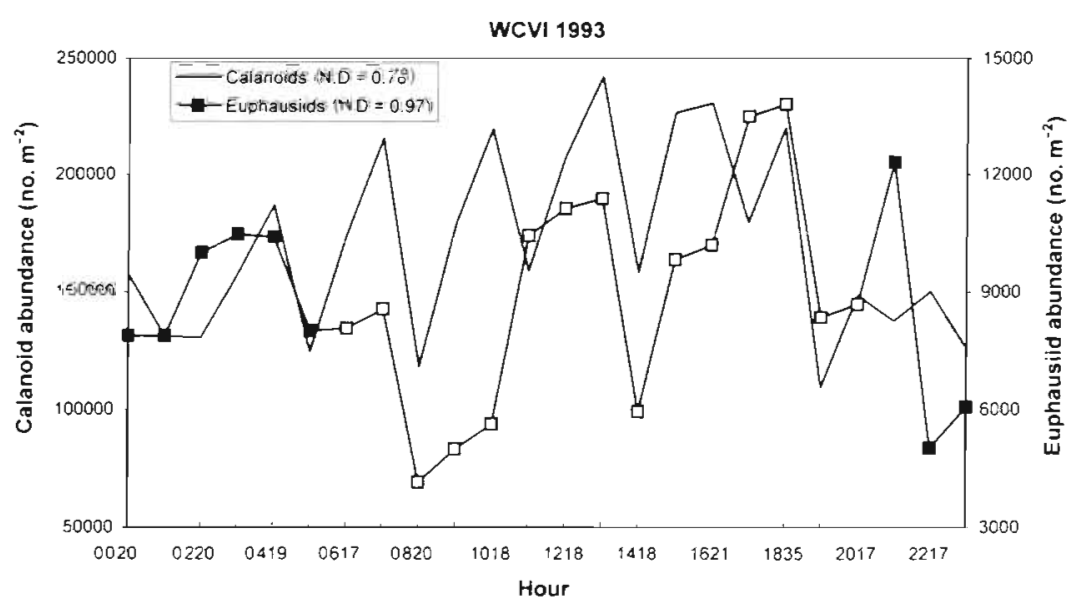

Fig. 5. Changes in calanoid copepod and euphausiid abundances over time, as determined from day ( $\square$ ) and night (a) bongo tows at WCVI in 1993. Estimated night:day $(N: D)$ catch ratios shown in parentheses make any generalizations about N:D catch ratios and the sex of euphausiids (Table 5).

\section{DISCUSSION}

In this study we evaluated for changes in night versus day abundance estimates of zooplankton as measured using oblique bongo net tows at 2 stations in southern British Columbia. The data were evaluated by considering (1) 2 generic groups of zooplankton, (2) 13 zooplankton taxa, and (3) life history stage and sex.

We found relatively few statistically significant differences between night and day catches of calanoid copepod genera, life history stages, or sexes. The species, stages, and sexes that exhibited significantly higher $\mathrm{N}: \mathrm{D}$ ratios tended to be the largest copepods. For example, female Eucalanus bungii and female Calanus spp. females had significantly higher N.D calch ratios and they are 6 to $8 \mathrm{~mm}$ and 2.6 to $3.1 \mathrm{~mm}$ in length, respectively (Fig 7). Verheye \& Field (1992) also noted that N:D differences in catch were higher in larger stages of Calanoides carinatus, with adult females exhibiting the highest $N: D$ catch ratio of 2.7. At this time there is insufficient information available to determine if the higher $\mathrm{N}: \mathrm{D}$ catch ratios of larger copepods are related to better visual detection of the bongo net, or detection of the bow-wave of 
Table 2. Night to day (N:D) catch ratios for selected zooplankton taxa sampled at WCVI and SOFG for 1993 to 1995 . N:D ratios significantly $>2$ or $<0.5$ are given in bold $(\mathrm{p}<0.05)$. Note: $\mathrm{N}$ : $\mathrm{D}$ for all years combined calculated from raw data not ratio data

\begin{tabular}{|c|c|c|c|c|c|c|c|c|c|}
\hline \multirow{2}{*}{ Taxon } & \multicolumn{3}{|c|}{ SOFG } & \multicolumn{3}{|c|}{ WCVl } & \multirow{2}{*}{$\begin{array}{c}\text { SOFG } \\
1993-1995\end{array}$} & \multirow{2}{*}{$\begin{array}{c}\text { WCVI } \\
1993-1995\end{array}$} & \multirow{2}{*}{$\begin{array}{c}\text { Both stations } \\
\text { 1993-1995 }\end{array}$} \\
\hline & 1993 & 1994 & 1995 & 1993 & 1994 & 1995 & & & \\
\hline Centropages spp. & 0.53 & 0.82 & 2.89 & & 1.55 & 0.21 & 0.86 & 0.75 & 0.72 \\
\hline Oithona spp. & 0.52 & 0.59 & 1.24 & 0.97 & 0.32 & 0.99 & 0.95 & 0.69 & 0.82 \\
\hline Chaetognatha & 0.34 & 0.96 & 0.72 & 1.06 & 1.25 & 1.10 & 0.52 & 1.14 & 0.85 \\
\hline Thecosomata & 0.83 & 0.79 & 0.77 & 0.90 & & 0.39 & 0.90 & 0.90 & 0.80 \\
\hline Hyperiidea & 0.28 & 1.91 & 1.25 & 0.88 & & 0.45 & 0.95 & 0.74 & 0.91 \\
\hline Euphausia pacifica & 4.07 & 2.60 & 0.50 & 7.58 & 1.63 & 10.57 & 2.20 & 10.25 & 4.29 \\
\hline Thysanoessa spinifera & 2.28 & & & 1.61 & 4.89 & 3.96 & & 5.17 & 4.49 \\
\hline Cirripedia & 0.27 & & 0.71 & & 0.94 & 1.29 & 0.55 & 1.20 & 0.45 \\
\hline Fish/Teleostei larvae & 1.46 & 1.59 & 1.48 & 0.26 & 0.15 & 0.10 & 1.58 & 0.80 & 0.18 \\
\hline Ostracoda & 1.23 & 1.45 & 1.46 & 1.71 & & & 1.11 & 3.46 & 1.47 \\
\hline Acartia spp. & 1.28 & 0.62 & 0.73 & 1.10 & 0.99 & 1.05 & 1.36 & 0.97 & 0.90 \\
\hline Clausocalanus spp. & & 1.22 & & 0.98 & 1.54 & 3.09 & & 0.73 & 0.92 \\
\hline Neocalanus spp. & 0.30 & 0.36 & 1.60 & 0.98 & & 0.50 & 0.97 & 1.12 & 0.80 \\
\hline Paracalanus spp. & 0.50 & 0.49 & 0.72 & 0.66 & 1.02 & 0.23 & 0.41 & 0.93 & 0.33 \\
\hline Pseudocalanus spp. & 0.42 & 0.44 & 2.64 & 0.85 & 0.54 & 0.69 & 0.46 & 0.85 & 0.60 \\
\hline Calanus marshallae & 1.35 & 0.76 & 0.62 & & 1.41 & 0.82 & 1.26 & 0.95 & 1.59 \\
\hline Calanus pacificus & & 0.66 & 2.64 & 0.18 & 1.61 & 0.73 & 1.66 & 1.32 & 2.22 \\
\hline Eucalanus bungii & 0.63 & 1.4 .61 & 0.57 & 0.56 & & 0.44 & 2.01 & 1.26 & 0.75 \\
\hline Metridia pacifica & 0.73 & 1.19 & 0.83 & 1.14 & 1.15 & 4.52 & 0.89 & 1.11 & 1.00 \\
\hline Oncaeidae & 0.64 & 0.87 & 1.69 & & & & 0.60 & & 0.38 \\
\hline
\end{tabular}

the net, or to their being less available to the sampler than smaller copepods (Mauchline 1998).

Day abundance estimates for small-bodied zooplankton were occasionally found to be 2 to 3 times higher than night estimates (e.g. Pseudocalanus spp.). Brinton \& Townsend (1981) also noted that sampling 3 to $6 \mathrm{~mm}$ euphausiids (Euphausia pacifica) using bongo nets and $1 \mathrm{~m}$ ring nets, in summer, was more effective in the daytime than at night. Robinson \& Ware (1994) indicated that copepod abundances were 1.5 to 3 times higher in daytime bongo catches compared to night time catches. In this study, because average abundances were depth-integrated, the lower catches of some smaller copepods during the night suggests that they migrated below the maximum depth sampled by the bongo net. However, because sampling was conducted to within $5 \mathrm{~m}$ of the bottom, and the maximum depths sampled were substantially deeper than the depths to which copepods can vertically migrate (Mauchline 1998), we discount the idea that our nighttime copepod estimates were low. The high daytime catches of copepods, however, may be related to environmental conditions at the time of sampling. For example, there was a significant positive correlation between the east-west component of tidal velocity and abundance of copepods at SOFG in 1993 (Fig. 8). Overall, we suspect that the low N:D catch ratios of smaller zooplankton were determined primarily by environmental conditions at the time of sampling rather than behavioral responses to the bongo net.

The strongest evidence for significant differences between night and day abundance estimates comes from sampling the euphausiids, particularly the adults. We found $\mathrm{N}: \mathrm{D}$ catch ratios averaged between 4 and 5 for the 2 main species caught, Thysanoessa spinifera and Euphausia pacifica. The average N:D catch ratios estimated for the euphausiids were near the low end of the range of maximum N:D catch ratios reported for a variety of euphausiids in other studies (Table 6). Overall, higher night catches were expected for euphausiids because they were not sampled effectively during daylight hours due to vertical migratory behavior and to their visual avoidance of the sampling net.

Table 3. N:D catch ratios by stage and sex for calanoids caught at WCVI and SOFG. C1. copepodite 1 ; C2: copepodite 2 ; C3: copepodite 3 ; C4: copepodite 4; C5: copepodite 5. N:D ratios in bold: statistically significant differences between night and day abundances $(p<0.05)$

\begin{tabular}{|lcccccccc|}
\hline & C1 & C2 & C3 & C4 & C5 & Adult & Male & Female \\
\hline WCVI-93 & 0.62 & 0.82 & 0.72 & 0.67 & 0.79 & 0.83 & 0.98 & 0.60 \\
SOFG-93 & $\mathbf{0 . 5 0}$ & 0.56 & 0.62 & 0.86 & 0.76 & 0.70 & & $\mathbf{1 7 . 4 3}$ \\
SOFG-94 & 0.44 & 0.72 & 0.81 & 1.00 & 1.27 & 1.09 & 0.03 & 0.00 \\
WCVI-94 & 0.95 & 0.97 & 0.72 & 1.00 & 1.13 & 1.23 & 0.84 & 2.18 \\
WCVI-95 & 1.52 & 1.11 & 0.80 & 0.65 & 0.66 & 0.69 & 2.87 & 1.23 \\
SOFG-95 & 1.44 & 0.85 & 1.07 & 0.90 & 1.03 & 0.95 & & \\
\hline
\end{tabular}


Table 4. N:D catch ratios for 3 life history stages, copepodite 4 (C4), copepodite 5 (C5), and adult (Ad), and for 4 species of calanoid copepods. Limited data is also shown for C5 males and females and adults for each species. N:D ratios in bold: statistically significant differences between night and day abundances $(p<0.05)$

\begin{tabular}{|c|c|c|c|c|c|}
\hline Station-year & Life history stage & Calanus spp. & Pseudocalanus spp. & Eucalanus bungii & Metridia pacifica \\
\hline \multirow[t]{3}{*}{ SOFG-93 } & $\mathrm{C} 4$ & 1.18 & 0.90 & 0.93 & 0.53 \\
\hline & C.5 & 1.03 & 0.84 & 0.71 & 0.75 \\
\hline & $\mathrm{Ad}$ & 0.48 & 0.68 & 0.20 & 0.82 \\
\hline \multirow[t]{3}{*}{ WCVI-93 } & $\mathrm{C} 4$ & 1.10 & 0.70 & 3.1 & 0.63 \\
\hline & C5 & 1.71 & 0.75 & 2.45 & 0.79 \\
\hline & $\mathrm{Ad}$ & 1.57 & 0.77 & 1.66 & 3.27 \\
\hline \multirow[t]{3}{*}{ SOFG-94 } & $\mathrm{C} 4$ & & 0.43 & & 1.64 \\
\hline & $\mathrm{C} 5$ & 2.08 & 1.02 & 1.13 & 1.38 \\
\hline & Ad & & 1.09 & & 0.90 \\
\hline \multirow[t]{3}{*}{ WCVI-94 } & $\mathrm{C} 4$ & 2.75 & 0.76 & & 0.68 \\
\hline & C5 & & 1.09 & & 1.21 \\
\hline & Ad & & 1.22 & & 1.80 \\
\hline \multirow[t]{3}{*}{ SOFG-95 } & $\mathrm{C} 4$ & 7.5 & 1.48 & 0.85 & 0.65 \\
\hline & C5 & 4.1 & 0.95 & 0.61 & 0.89 \\
\hline & Ad & 1.94 & 0.91 & 1.28 & 0.97 \\
\hline \multirow[t]{3}{*}{ WCVI-95 } & $\mathrm{C} 4$ & & 0.38 & 0.43 & 1.42 \\
\hline & C5 & 0.27 & 0.28 & 1.42 & 2.46 \\
\hline & $\mathrm{Ad}$ & 0.14 & 0.42 & & 8.49 \\
\hline WCVI-93 & Ad males & 1.0 & 0.82 & 0.34 & 2.8 \\
\hline WCVI-93 & Ad females & 2.1 & 0.63 & 2.32 & 3.7 \\
\hline WCVI-93 & C5 males & & 0.68 & 1.87 & 0.65 \\
\hline WCVI-93 & C5 females & & 0.68 & 1.20 & 1.1 \\
\hline
\end{tabular}
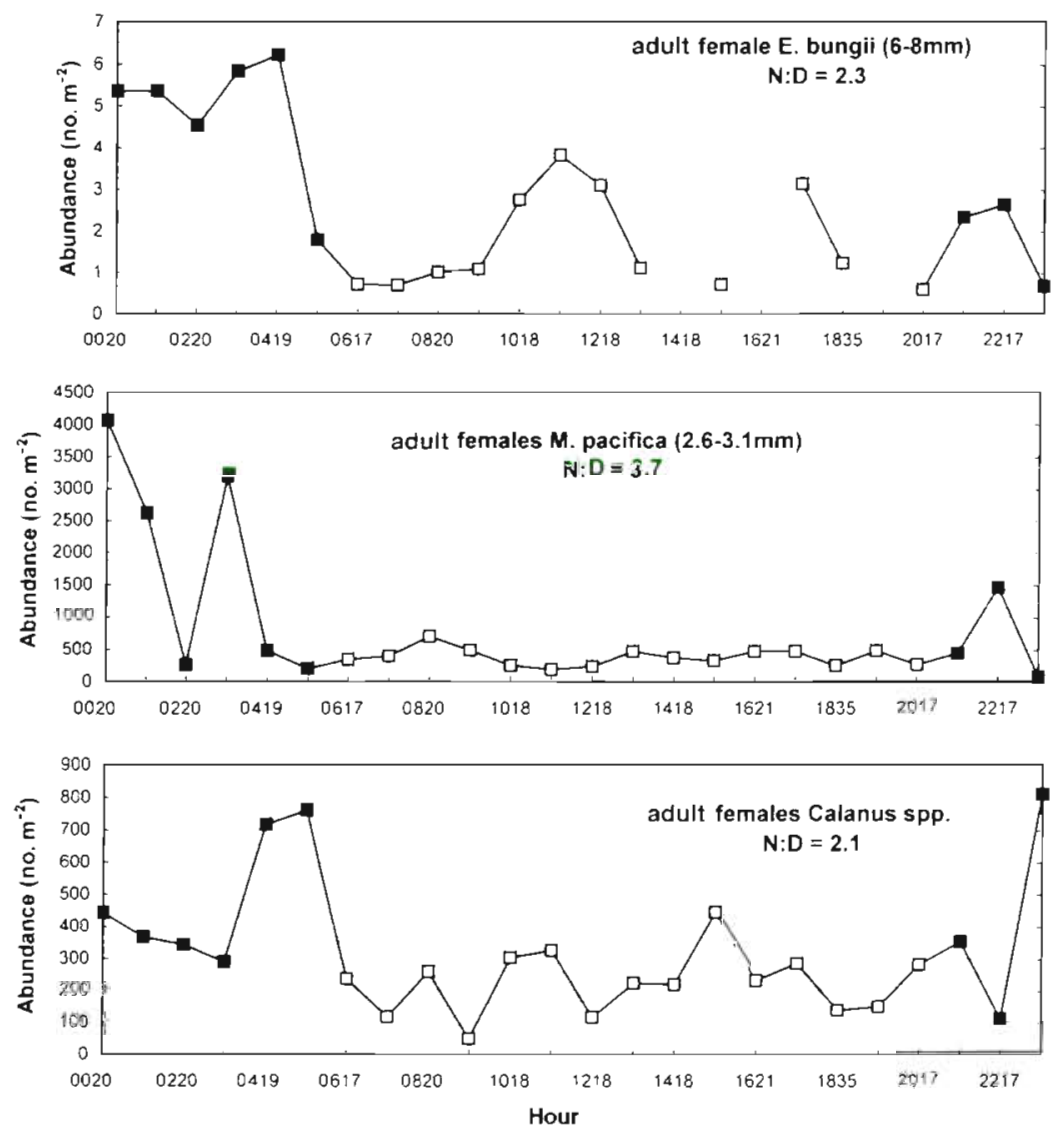

An interesting property of the N:D ratios calculated for Euphausia pacifica is that they varied by more than an order of magnitude over the course of the study. This result implies that many factors potentially influence the euphausiid N:D catch ratios. We had sufficient data to examine only a couple of these factors. One coastal oceanic factor that may influence the hourly abundance estimates made by the bongo net are tidal conditions. Hourly tidal model estimates were obtained for each station from $M$. Foreman, Institute of Ocean Sciences, Sidney, British Columbia. The tidal estimates included tidal height above mean tide (m), and tidal current velocity averaged for the whole water column (north-south and eastwest components in $\mathrm{cm} \mathrm{s}^{-1}$ ). We con-

Fig. 7. Significant N:D catch ratios and abundances over time for 3 species of calanoid copepods sampled dunng night ( $\mathbf{m}$ ) and day (ㅁ). Data from WCVI, 1993. Missing lines: no copepods caught 
Table 5. N:D catch ratios calculated for various stages and sexes of euphausiids. Statistically significant differences between night and day abundances: " $p<0.05, " p<0.01$

\begin{tabular}{|lcccccccc|}
\hline & Nauplius & Furcilia & Calyptopis 1 & Calyptopis 2 & Calyptopis 3 & Adult & Male & Female \\
\hline WCVI-1993 & 1.0 & 1.2 & 0.8 & 1.1 & 0.9 & $4.4^{*}$ & $10.5^{*}$ & 2.8 \\
SOFG-1993 & 0.8 & 1.0 & 1.3 & 0.8 & 0.8 & $4.0^{*}$ & \\
SOFG-1994 & & 0.7 & & & & $2.2^{*}$ & 1.3 & 0.7 \\
WCVI-1994 & & 1.0 & & & & $4.7^{*}$ & 13.0 & \\
SOFG-1995 & 1.4 & 0.4 & 2.1 & 1.0 & 0.4 & 0.6 & 3.7 \\
WCVI-1995 & 0.6 & 0.6 & & 0.3 & & $12.0^{*}$ & \\
Combined & 0.8 & 0.7 & 1.1 & 1.0 & 0.6 & $3.6^{*}$ & 0.9 & 0.4 \\
\hline
\end{tabular}

ducted correlation analyses between hourly estimates of abundance of euphausiids and the hourly tidal data.

Three of the 6 correlations between Euphausia pacifica abundance and tidal height were found to be statistically significant. Two of these correlations indicated higher euphausiid catches with higher tidal height at WCVI-95 and SOFG-94 (Fig 9), while a significant negative correlation was detected between tidal height and E. pacifica abundance at SOFG-95. The correlations detected may be spurious because spring tides in coastal BC waters are strongly diurnal, and in early summer the timing of lower low water is during late morning. Hence, diurnal tides are approximately synchronous with daylight, and they may be confounded variables (Fig. 9).

It is also possible that ambient light during sampling influences catches of Euphausia pacifica, primarily as a result of increased visual detection of the net with variable light levels in the water column (Mauchline 1980). It has also been shown that the vertical range of euphausiids is directly proportional to the intensity of moonlight and that the range of depth distribution deepens in relation to the full moon (Roger 1974 in Mauchline 1980). In this study, sampling occurred over a gradient of moonlight conditions ranging from a full moon (WCVI-94) to a new moon (WCVI-95). We found a significant positive correlation between $E$. pacifica $N: D$ catch ratios and the time of moon set $(r=0.81 ; n=6, p<0.05)$. The time that the moon sets is directly related to the number of days from a full moon. Thus, the $E$. pacifica $\mathrm{N}: \mathrm{D}$ catch ratios increase by about 5 times when sampling is conducted closer to a new moon because night abundance estimates increase. We did not measure light intensity in the water column but presumably with a new moon there is less light in the water column at night, and subsequently less visual avoidance of the bongo sampler by the euphausiids (Anderson \& Nival 1991).

Another factor that may also be responsible for the large interannual and interstation variability observed in Euphausia pacifica N:D ratios is the inherent temporal and spatial variability in euphausid populations. For example, we know that euphausids such as $E$. pacifica are highly patchy in their horizontal distributions on the southern Vancouver Island shelf, and that this patchiness changes year to year. In some years euphausiids occur in distinct patches because of 'good' local upwelling conditions, while in other years euphausiids are more dispersed because of poor coastal upwelling (Ware \& McFarlane 1995). We can, however, likely discount the effects of seasonal variability on euphausiid N:D catch ratios because sampling was conducted in the spring of each year, the period before the arrival of the major euphausiid predator, Pacific hake Merluccius productus. These voracious predators can significantly influence the abundance of euphausiids in a local region (Robinson \& Ware 1994, Ware \& McFarlane 1995, Robinson unpubl. data). It is also

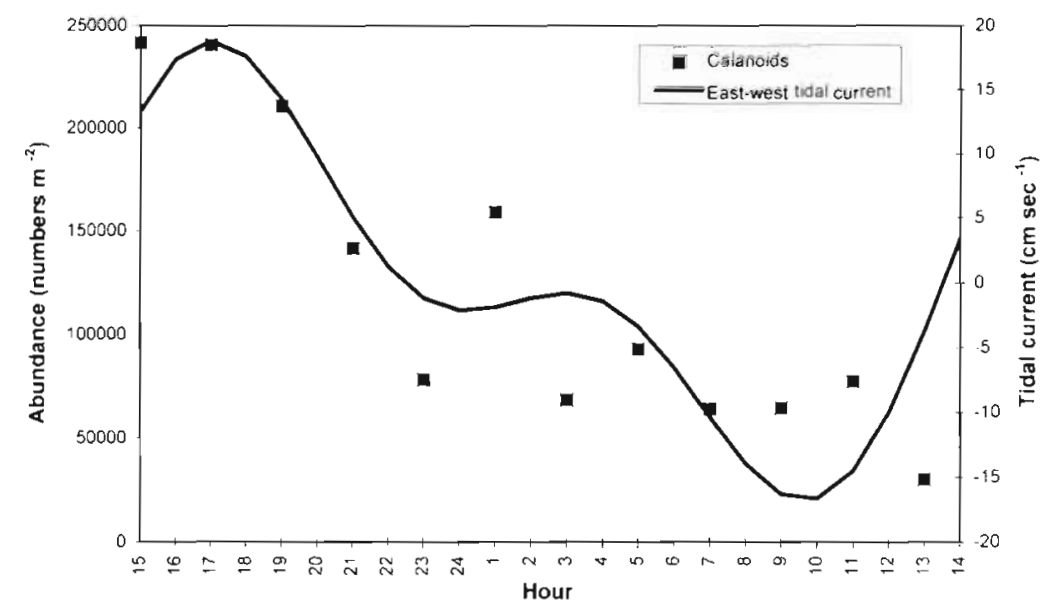

Fig. 8. Relationship between abundances of calanoid copepods (all speries, stages and sexes) and the east-west component of tidal current velucity at SOFG in 1993 
Table 6. Estımated maximum (and average) N:D euphausiid catch ratios using various sampling gear (modified from Robinson \& Ware 1994). BN: bongo net; PN: plankton net; PL: plummet net; M: Miller net; MN: MOCNESS; BI: BIONESS

\begin{tabular}{|llll|}
\hline Species & Gear & N:D catch ratio & Source \\
\hline Euphausia pacifica & $\mathrm{BN}$ & 10 & Youngbluth (1976) \\
Euphausia pacifica & $\mathrm{PN}$ & 20 & Brinton \& Townsend (1981) \\
& $\mathrm{BN}$ & 20 & Fulton et al. (1982) \\
Euphausia pacifica (St. of Georgla) & $\mathrm{BN}$ & 20 & Fulton et al. (1982) \\
Euphausia pacifica (WCVI) & $\mathrm{BN}$ & 10 & Hovekamp (1989) \\
Euphausia pacifica (October) & $\mathrm{PL}$ & 31 (Avg. 11) & Hovekamp (1989) \\
Euphausia pacifica (February) & $\mathrm{PL}$ & 64 (Avg. 30) & This study \\
Euphausia pacifica & $\mathrm{BN}$ & 10.6 (Avg. 4.3) & Pillar (1984) \\
Euphausia lucens & $\mathrm{BN}$ & $67-118$ & Pillar (1984) \\
Euphausia Iucens & $\mathrm{M}$ & 18.5 & Wiebe et al. (1982) \\
Nematoscelis megalops & $\mathrm{MN}$ & 63 (Avg.) 15 & Fulton et al. (1982) \\
Thysanoessa longipes & $\mathrm{BN}$ & 6 & Cochrane et al. (1991) \\
Meganyctiphanes norvegica & $\mathrm{BI}$ & 14 (Avg.) 7 & Smith (1991) \\
Thysanoessa raschi and Thysanoessa inermis & $\mathrm{MN}$ & 7 & Brinton (1967) \\
Thysanoessa gregaria & $\mathrm{PN}$ & 50 (Avg.) 23 & Robinson \& Ware (1994) \\
Thysanoessa spinifera & $\mathrm{BN}$ & 20 & This study \\
Thysanoessa spinifera & $\mathrm{BN}$ & 5.2 (Avg.) 4.5 &
\end{tabular}

probable that the concentration and size of a euphausiid patch changes over the diel scale as a result of alongshore transport (Mackas et al. 1997). Alongshore transport of adults occurs primarily at night when the adults are in the surface layer, and has been estimated for the southern $\mathrm{BC}$ shelf break to result in horizontal displacements of 2 to $5 \mathrm{~km} \mathrm{~d}^{-1}$. In this study it was assumed that the same zooplankton patch was sampled continuously over the $24 \mathrm{~h}$ period, but this assumption is highly dubious.

In this study, we have provided evidence that $N: D$ catch ratios of euphausiids can vary widely from station to station or year to year, depending upon the time of sampling and on local oceanic conditions. It is important to recognize that bongo samples collected at night represent a biased estimate of euphausiid population abundance because of the avoidance by larger animals. For instance, the modal size of euphausiids sampled using a bongo net at night was found to be substantially lower than the modal size obtained from stomach samples of Pacific hake Merluccius productus (10 $\mathrm{mm}$ versus $17 \mathrm{~mm}$; R. Tanasichuk, Fisheries and Oceans Canada, $\mathrm{Na}$ naimo, unpubl. data). This result suggests that both hake and bongo net are biased towards sampling a specific portion of the euphausiid population. A second factor that results in biased abundance estimates when using bongo nets is the fact that euphausiid populations are very patchy, and the bongo net is a discrete sampler that will occasionally hit or miss a patch. This is exemplified by noting that some high, but not significantly different, N:D catch ratios were inflated by a single abundance value from sampling a zooplankton patch (Fig. 4). To overcome biases in zooplankton samples from bongo nets, it would be wise to use continuous sampling methods (e.g. optics or acoustics; Cochrane et al. 1991, Herman et al. 1993) to generate quantitative abundance estimates. If euphausiids must be sampled using bongo nets, then we recommend that $24 \mathrm{~h}$ continuous sampling be conducted as part of the program to quantify variability in their abundance or biomass estimates.

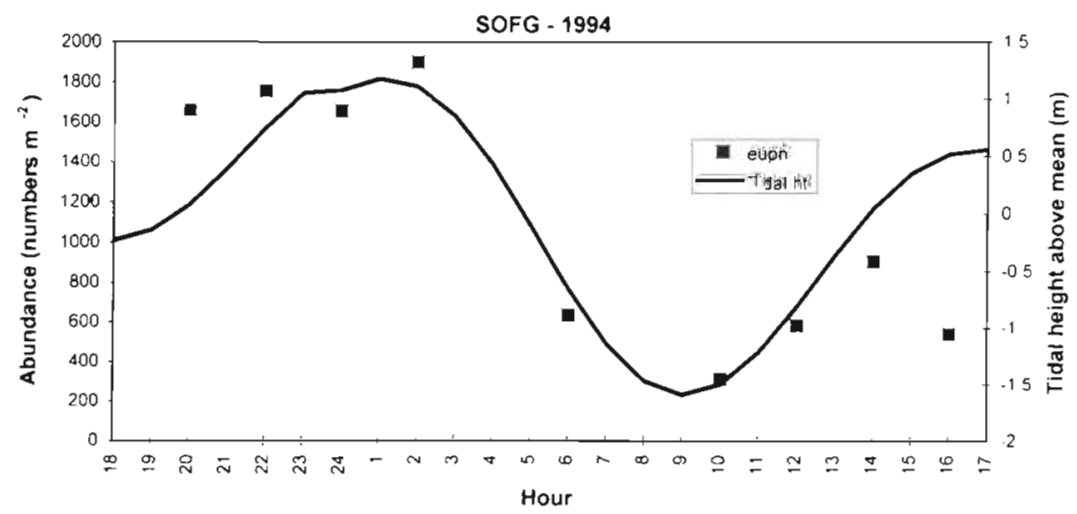

Fig. 9. Relationship between abundance estimates of euphausiids (all species, stages, and sexes) and tidal height at SOFG in 1994 
Acknowledgements. We thank Dr L. Ejsymnot and the Polish Plankton Identification and Sorting Center for carefully sorting the zooplankton samples. Dr M. Foreman of the Institute of Ocean Sciences (DFO) kindly provided tidal height model estimates. Dr J. Napp of the National Marine Fisheries Service, Seattle, Dr D. Mackas (DFO), and 3 anonymous reviewers provided valuable comments on the manuscript.

\section{LITERATURE CITED}

Anderson VP, Nival (1991) A model of the diel vertical migration of zooplankton based on euphausiids. J Mar Res 49: $153-175$

Beamish RJ (ed) (1995) Climate change and northern fish populations. Can Spec Publ Fish Aquat Sci 1.21

Brinton E (1967) Vertical migration and avoidance capability of euphausiids in the California Current. Limnol Oceanogr 12:451-483

Brinton E. Townsend AW (1981) A comparison of euphausiid abundances from bongo and $1-\mathrm{m}$ CalCOFI nets. CalCOFI Rep 22:111-125

Cochrane NA, Sameoto D, Herman AW, Neilson J (1991) M.ultiple-frequency acoustic backscattering and zooplankton aggregations in the inner Scotian Shelf basins. Can J Fish Aquat Sci 48:340-355

Fulton J, Arai MN, Mason JC (1982) Euphausiids, coelenterates, ctenophores, and other zooplankton from the Canadian Pacific coast ichthyoplankton survey, 1980. Can Tech Rep Fish Aquat Sci 1125

Herman AW, Cochrane NA, Sameoto DD (1993) Detection and abundance estimation of euphausiids using an optical plankton counter. Mar Ecol Prog Ser 94:165-173

Hovekamp S (1989) Avoidance of nets by Euphausia pacifica in Dabob Bay. J Plankton Res 11:907-924

Mackas DL (1995) Interannual variability of the zooplankton community off southern Vancouver Island. In: Beamish RJ (ed) Climate change and northern fish populations. Can Spec Publ Fish Aquat Sci 121:603-615

Mackas DL, Kieser R, Saunders M, Yelland DR, Brown RM, Moore DF (1997) Aggregation of euphausiids and Pacific hake (Merluccius productus) along the outer continental shelf off Vancouver Island. Can J Fish Aquat Sci 54: 2081-2096

Mauchline J (1980) The biology of the mysids and euphausiids. Adv Mar Biol 18

Mauchline J (1998) The biology of the calanoid copepods. Adv Mar Biol 33

Pillar SC (1984) A comparison of the performance of four zooplankton samplers. S Afr J Mar Scl 2:1-18

Editorial responsibility: Otto Kinne (Editor),

Oldendorf/Luhe, Germany
Rice WR (1989) Analyzing tables of statistical tests. Evolution 43:223-225

Robinson CLK, Ware DM (1994) Modelling pelagic fish and plankton trophodynamics off southwestern Vancouver Island, British Columbia. Can J Fish Aquat Sci 51:1.737-1751

Shaw W (1994) Oceanographic sampling manual for the longterm cooperative plankton research monitoring program (COPRA). Can Tech Rep Fish Aquat Sci 1976

Siefert DLW, Incze LS (1991) Zooplankton of Shelikof Strait. Alaska, April and May 1989: data from Fisheries-Oceanography Coordinated Investigations (FOCI) Cruises. Alaska Fisheries Science Center Processed Report 91-16, National Marine Fisheries Service, Seattle

Simard Y, Mackas DL (1989) Mesoscale aggregations of euphausiid sound scattering layers on the continental shelf off Vancouver Island. Can J Fish Aquat Sci 46: $1238-1249$

Smith SL (1991) Growth, development and distribution of the euphausiids Thysanoessa raschii (M. sars) and Thysanoessa inermis (Kroyer) in the southeastern Bering Sea. In: Sakshaug E, Hopkins CCE, Oritsland, NA (eds) Pro Mare Symp Polar Mar Ecol, Trondheim, 12-16 May 1990. Polar Res 10(2):461-478

Sokal RR, FJ Rohlf (1981) Biometry. Freeman and Company. New York

Thomson RE, Hickey BM, LeBlond PH (1989) The Vancouver Island coastal current: fisheries barrier and conduit. In: Beamish RJ, McFarlane GA (eds) Effects of ocean variability on recruitment and an evaluation of parameters used in stock assessment models. Can Spec Publ Fish Aquat Sci 108:265-296

Verheye HM, Field JG (1992) Vertical distribution and diel vertical migration of Calanoides carinatus (Kroyer, 1849) development stages in the southern Benguela upwelling region. J Exp Mar Biol Ecol 158(1992):123-140

Ware DM, McFarlane GA (1995) Climate induced changes in hake abundance and pelagic community interactions in the Vancouver Island Upwelling System. In: Beamish RJ (ed) Climate change and northern fish populations. Can Spec Publ Fish Aquat Sci 121:509-521

Ware DM, Thomson RE (1991) La Perouse Project: sixth annual report, 1990 Canadian Department of Fisheries and Oceans Internal Report. Pacific Biological Station, Nanaimo, BC

Wiebe $\mathrm{PH}$, Boyd SH, Davis BM, Cox JL (1982) Avoidance of towed nets by the euphausiid Nematoscelis megalops. Fish Bull US 80:75-91

Youngbluth MJ (1976) Vertical distribution and diel migration of euphausiids in the central region of the California Current. Fish Bull US 74:925-936

Submitted: May 5, 1998; Accepted: August 3, 1998

Proofs received from author(s): November 17, 1998 